\title{
A new Lepeophtheirus (Copepoda: Siphonostomatoida: Caligidae) from Isla del Coco National Park, Costa Rica, Eastern Tropical Pacific
}

\author{
Eduardo Suárez-Morales \& Rebeca Gasca \\ El Colegio de la Frontera Sur (ECOSUR), Unidad Chetumal, Av. Centenario Km 5.5, Chetumal, Quintana Roo 77000, \\ México; esuarez@ecosur.mx
}

\author{
Received 02-III-2012. C Corrected 30-V-2012. Accepted 24-IX-2012.
}

\begin{abstract}
Among the several groups of copepods that are teleost parasites, the siphonostomatoid family Caligidae is by far the most widespread and diverse. With more than 108 nominal species, the caligid genus Lepeophtheirus von Nordmann is one of the most speciose. There are no reports of this genus in Costa Rican waters. A new species of Lepeophtheirus is herein described based on female specimens collected from plankton samples in waters off Bahía Wafer, Isla del Coco, an oceanic island in the Eastern Tropical Pacific. The new species, L. alvaroi sp. nov., has some affinities with other congeners bearing a relatively short abdomen, a wider than long genital complex and a 3-segmented exopod of leg 4. It differs from most of these species by the presence of an unbranched maxillular process and by the relative lengths of the terminal claws of leg 4, with two equally long elements. It is most closely related to two other Eastern Pacific species: L. dissimulatus Wilson, 1905 and L. clarionensis Shiino, 1959. It differs from these species by the proportions and shape of the genital complex, the shape of the sternal furca, the relative length of the maxillar segments, the absence of a pectiniform process on the distal maxillar segment, the length of leg 4 and the armature of leg 5 . The new species represents the first Lepeophtheirus described from Costa Rican waters of the Pacific. The low diversity of this genus in this tropical region is explained by its tendency to prefer hosts from temperate latitudes. Until further evidence is found, the host of this Lepeophtheirus species remains unknown. Citation: Suárez-Morales, E. \& R. Gasca. 2012. A new Lepeophtheirus (Copepoda: Siphonostomatoida: Caligidae) from Isla del Coco National Park, Costa Rica, Eastern Tropical Pacific. Rev. Biol. Trop. 60 (Suppl. 3): 235-242. Epub 2012 Dec 01.
\end{abstract}

Key words: parasitic crustaceans, zooplankton, diversity, copepods.

Caligids are the most widely distributed group of siphonostomatoid copepods in the world seas (Ho et al. 2000, Boxshall \& Halsey 2004). Lepeophtheirus von Nordmann is the second most diverse genus of the family Caligidae; the most speciose is Caligus Müller, which contains more than 250 species. Currently, it is known to contain 108 nominal species (Ho et al. 2001). Morphologically, this genus is characterized by the lack of lunules, a three-segmented exopod of the fourth leg, and the presence of a postantennary process (Ho \& Lin 2004). Members of this genus are known as parasites of a wide variety of teleosts and elasmobranchs (Kabata 1979, Cressey \& Cressey 1980, Ho \& Lin 2004) and one species, L. salmonis Krøyer, is deemed as the most serious parasite of farmed fish (Jackson \& Minchin 1992; Johnson et al. 2004).

Caligid copepods attach themselves to the cavity of the mouth, the gills, and the operculum of their hosts (Boxshall \& Montú 1997). However, adult caligids can also be found in the water column and some species are known only from plankton surveys (Venmathi Maran \& Ohtsuka 2008). Each of these two main genera of the Caligoida, Caligus and Lepeophtheirus, appear to have a well-defined tendency to distribute at different latitudes. The former genus is clearly more diverse in tropical waters and Lepeophtheirus parasitizes mainly fishes 
from temperate-cold latitudes (Ho \& Lin 2004, Muñoz \& Olmos 2007). There are only a few works dealing with the caligid fauna of the Eastern Tropical Pacific and only a reduced number of species of this genus has been recorded in the region: L. dissimulatus Wilson, 1905, $L$. parvus Wilson, 1908, L. clarionensis Shiino, 1959, L. thompsoni Baird, 1850, and L. simplex Ho, Gómez \& Fajer-Avila, 2001 (Wilson 1905, Shiino 1959, Causey 1960, Ho et al. 2001).

As a part of a biological survey of the marine biota of the oceanic island Isla del Coco, Costa Rica, zooplankton samples were recorded at different sites and environments around this protected area (Morales-Ramírez 2008). During the examination of these samples female specimens of a species of Lepeophtheirus were observed. This caligid copepod was found to represent a new species, which is described in full based on female specimens.

\section{MATERIALS AND METHODS}

During the last week of November, 2001 an oceanographic cruise was carried out in neritic and oceanic waters of the Isla del Coco in order to evaluate different aspects of the geology and ecology of this marine protected area of the Eastern Tropical Pacific (Graziano 2001). Zooplankton samples were obtained at 6 stations located around the island: Bahía Chatham, Bahía Wafer, Wafer externa, Punta María, Isla Dos Amigos, Bahía Yglesias, and Cabo Atrevido. Plankton hauls were vertical (0-50m) and horizontal (3-4 min.). Standard plankton nets $(0.49 \mathrm{~m}$ mouth-diameter, 200 and $500 \mu \mathrm{m}$ mesh sizes) were used in each case. Samples were fixed in $4 \%$ formalin solution and then transferred to $70 \%$ ethanol for preservation and long-term storage. The caligid copepods were sorted from the samples collected at Bahía Wafer. Drawings were prepared using a camera lucida mounted on an E-200 Nikon compound microscope. Terminology of the body parts and appendages follows Ho and Lin (2004). A full description and illustrations of the females are provided. The holotype specimen was deposited in the collection of
Crustacea, Museum of Zoology, University of Costa Rica (MUZCR) and the paratype was deposited in the collection of Zooplankton at El Colegio de la Frontera Sur (ECOSUR) in Chetumal, Quintana Roo, Mexico (ECO-CHZ).

\section{RESULTS}

Order Siphonostomatoida Thorell, 1859

Family Caligidae Burmeister, 1835

Genus Lepeophtheirus von Nordmann, 1832

\section{Lepeophtheirus alvaroi sp. nov.}

(Figs. 1, 2)

Description of female: Body (Figs. 1A, 2A) lengths of two specimens: $2.28 \mathrm{~mm}$ (holotype) and $2.16 \mathrm{~mm}$ (paratype), excluding setae on caudal rami. Cephalothoracic shield robust, medially expanded, 1.15 times as long (1.6, $1.5 \mathrm{~mm})$ as it is wide $(1.4 \mathrm{~mm})$, including narrow marginal hyaline membranes. Genital complex relatively small $(400,330 \mu \mathrm{m})$, rounded, wider than long, about $24 \%$ the length of cephalothorax. Complex widest medially $(500,515 \mu \mathrm{m})$, naked surface; anterocentral portion tapering into fourth pediger, posterior margin rounded, not produced, bearing fifth legs. Abdomen short, about $23 \%$ the length of the genital complex. Abdominal margin abruptly tapering from genital complex, separated by weak cuticular suture; subquadrate, wider $(360,390 \mu \mathrm{m})$ than long $(120,130 \mu \mathrm{m})$, with pair of rounded processes on distal inner margin, between insertion of caudal rami (Fig. 1H). Caudal ramus small, subquadrate, $70 \mu \mathrm{m}$ long and $85 \mu \mathrm{m}$ wide, carrying 6 elements: short inner seta as long as ramus, 3 long terminal setae plus two short outer setae (Fig. $1 \mathrm{H})$, the outermost about 2.5 times as long as ramus (Figs. 1H, 2G).

Antennule (Fig. 1B) 2-segmented; proximal segment with shallow, incomplete suture on dorsal surface, segment armed with 26 plumose setae on frontal surface; second segment with 11 setae plus 2 aesthetascs on distal margin. Antenna 3-segmented (Fig. 1C); proximal segment largest, robust, with sharply pointed postero-medial process; second 


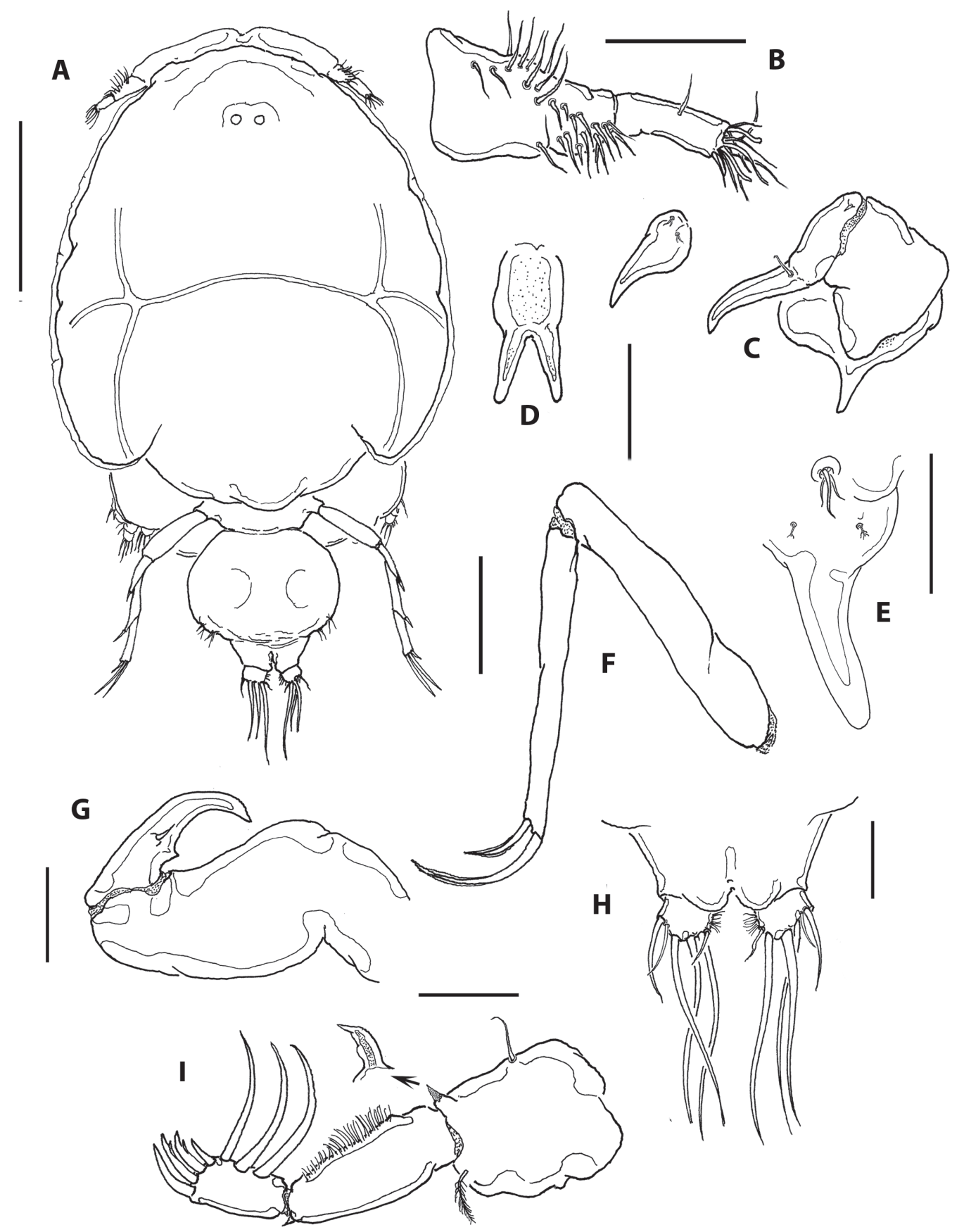

Fig. 1. Lepeophtheirus alvaroi sp. nov. from Isla del Coco, Costa Rica, female holotype. (A) habitus, dorsal view. (B) antennule. (C) antenna and postantennary process. (D) sternal furca. (E) maxillule. (F) maxilla. (G) maxilliped. (H) abdomen and caudal rami, ventral view. (I) leg 1 . Scale bars: $\mathrm{A}=0.5 \mathrm{~mm}, \mathrm{~B}-\mathrm{I}=0.1 \mathrm{~mm}$. 

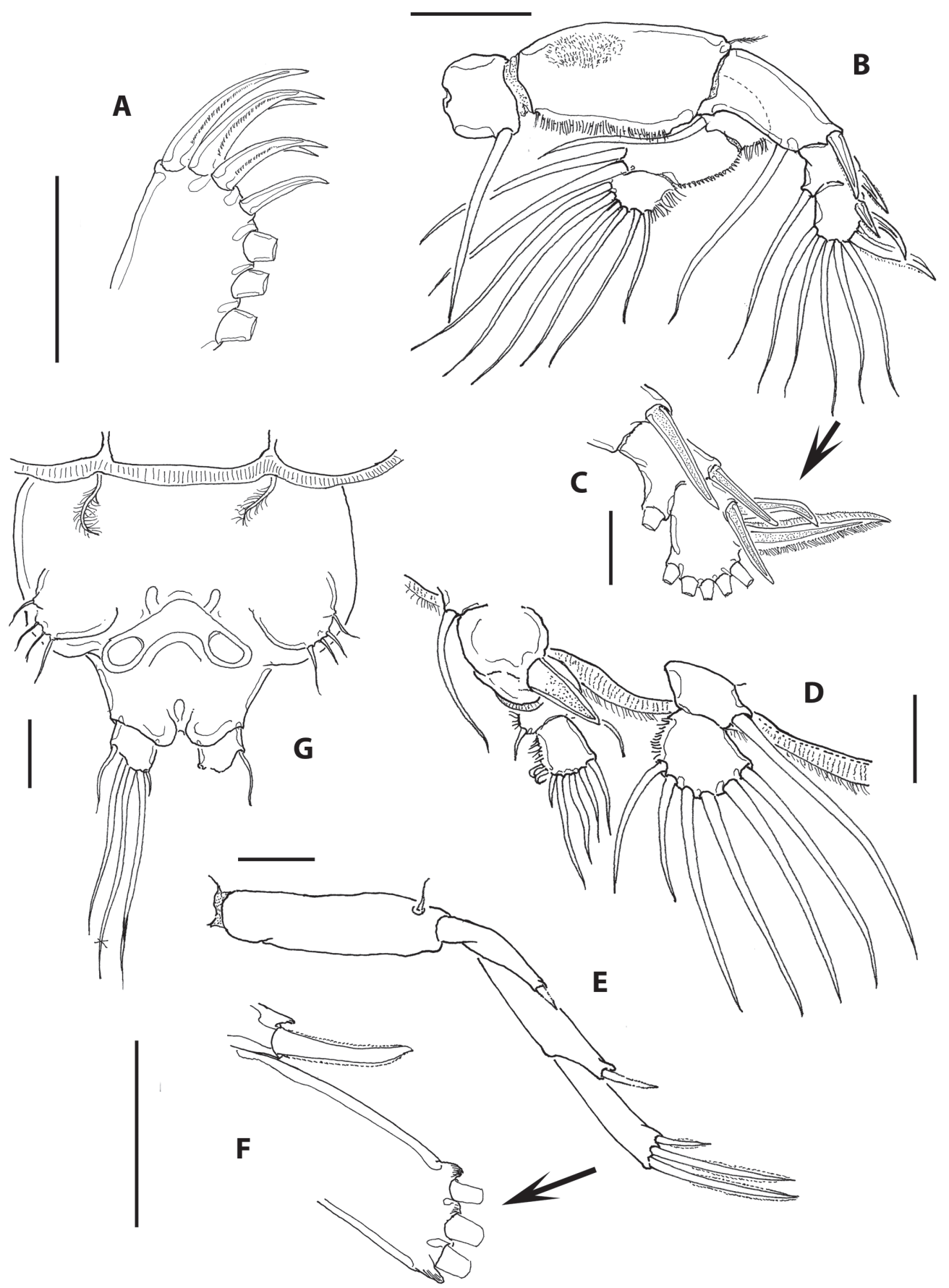

Fig. 2. Lepeophtheirus alvaroi sp. nov. from Isla del Coco, Costa Rica, female holotype. (A) detail of distal armature of leg 1 showing two elements with accessory spines; detail of distal basal process arrowed. (B) leg 2. (C) detail of distal exopodal segments of leg 2. (D) leg 3. (E) leg 4. (F) detail of distal armature of third exopodal segment of leg 4. (G) abdomen, ventral view, showing pair of spermatophores. Scale bars: A, B, D-F=0.1 mm, C, G=0.05 mm. 
segment relatively short, with small cuticular pad on posterior surface; third antennal segment claw-like, armed with short proximal and medial setae. Postantennal process unbranched, comprising broad base and subtriangular shaft; proximal surface with two papillae each bearing two slender setae (Fig. 1C). Sternal furca with large, subtriangular box and moderately divergent and distally blunt tines (Fig. 1D). Maxillule (Fig. 1E) comprising slender, unbranched pointed process, proximal papilla bearing 2 equal setae and one long seta. Two additional papillae with branched setal elements on medial proximal position. Maxilla (Fig. 1F) 2-segmented; proximal segment (lacertus) unarmed; distal segment (brachium) slender, slightly longer than first segment. Brachium without ornamentation or armature on outer edge, with 2 unequal elements (calamus and canna) terminally. Maxilliped (Fig. 1G) 3-segmented; proximal segment (corpus) largest but unarmed; middle and distal segments partially fused to form strong, sharply pointed claw with short medial spiniform seta.

Armature on rami of legs 1-4 as follows (Roman numeral indicating spines and Arabic numeral, setae):

\begin{tabular}{ccc} 
& exopod & endopod \\
Leg 1 & I-0; III,I,3 & (vestigial) \\
Leg 2 & I-1; I-1; III,5 & $0-1 ; 0-2 ; 6$ \\
Leg 3 & I-1; III,4 & $0-1 ; 6$ \\
Leg 4 & I- $0 ;$ I-0; III & (missing) \\
\hline
\end{tabular}

Leg 1 (Figs. 1I, 2A) protopod with short plumose outer seta and inner seta; endopod represented by short bulb-like process with acute distal end (arrowed in Fig. 1I). First segment of exopod longest, with short spiniform seta on outer distal corner; inner margin with row of short and medium-sized setules. Second segment about half the length of first one, middle 2 of 4 terminal elements on last exopodal segment with accessory setal processes (Fig. 2A); 3 curved subequal setae on medial margin. Leg 2 (Fig. 2B) with small coxa armed with large plumose inner seta on posterior edge; basis large, with small, plumose outer seta and medial patch of spinules. Inner margin ornamented with short setules. Distal exopodal segment with three spines; modified seta weakly sinusoid (Fig. 2C). Leg 3 (Fig. 3D) protopod (apron) with narrow marginal membrane, posterior edge with small, plumose setae at distal outer and distal inner corners. Both rami 2-segmented; exopodal spine on proximal segment robust. Two subdistal elements on third exopodal segment curled. Leg 4 (Fig. 2E) protopod with short, plumose outer seta on subdistal position; first exopodal segment slender, with short terminal spine. Pectens on third exopodal segment weakly developed, at insertion of each spine except middle one (Fig. 2F). Leg 5 represented by a broad rounded plate armed with three biserially plumose setae and an isolated papilla bearing a single plumose seta at posteroventral corner of genital complex (Fig. 2G).

Type material: holotype: adult female collected from the plankton at Bahía Wafer, Isla del Coco, Costa Rica, coll. J. Picado, November 4, 2001, specimen partially dissected, slide with appendages sealed with Entellan ${ }^{\circledR}$, specimen ethanol-preserved, vial (MZUCR-283501). Paratype: adult female from same locality and date, specimen undissected, ethanol-preserved, vial deposited in ECO-CHZ-07567.

Male: Unknown.

Host: Unknown.

Type locality: Bahía Wafer, Isla del Coco, Costa Rica $\left(5^{\circ} 32^{\prime} \mathrm{N}, 87^{\circ} 04^{\prime} \mathrm{W}\right)$, in the Eastern Tropical Pacific Ocean. Temperature at site of collection: $27^{\circ} \mathrm{C}$, salinity: $30 \mathrm{PSU}$, depth: $5.5 \mathrm{~m}$.

Etymology: This species is named after Dr. Alvaro Morales-Ramírez (CIMAR-University of Costa Rica), a Costa Rican zooplanktologist who has encouraged, for many years, different kinds of surveys of the planktonic fauna of Costa Rica and Central America.

Remarks: The specimens examined herein were identified as belonging to the genus Lepeophtheirus because of the absence of lunules, the anterior margin of the cephalothorax is not folded, and its possession of a three-segmented exopod of the fourth leg (Ho \& Lin 2004). There are many species of Lepeophtheirus 
(more than 50) with a relatively short abdomen (Castro \& Baeza 1981) as in the new species from Isla del Coco. However, the number of species to compare decreases when additional characters (i.e. structure and armature details of legs 4 and 5) are added (Dojiri 1979). Hence, the combination of characters of the new species is comparable with other congeners having: 1) a short, 1-segmented abdomen less than half the length of the genital complex; 2) a genital complex distinctly wider than long; 3) leg 4 exopod 3-segmented and longer than the protopod; 4) leg 4 with middle terminal claw as long as inner one; 5) accessory processes on terminal elements II and III of the exopod of leg 1. Among the species with more than three of these characters are L. exilipes Ho \& Lin, 2003, L. atypicus Lin, Ho \& Chen, 1996, L. goniistii Yamaguti, 1936, L. lagocephali Pillai, 1963, L. rotundipes Dojiri, 1979, and L. erecsoni Thompson, 1891.

Lepeophtheirus gonistii has a characteristic forked spine on the first exopodal segment of female leg 4, a structure which is simple in the new species. In both $L$. erecsoni and L. lagocephali the terminal claws of leg 4 decrease in length from the inner to the outer margin (Dojiri 1979, Boxshall \& Bellwood 1981), thus differing from the new species. In $L$. rotundipes the general habitus and the shape and proportions of the genital complex are different (see Dojiri 1979, Fig. 2G). The postantennal processes are relatively straight in L. alvaroi sp. nov. and strongly curved in $L$. rotundipes, the maxillule in $L$. rotundipes is forked $v s$. a single tine in specimens from Isla del Coco. The sternal furca is U-shaped in $L$. rotundipes whereas it is more V-shaped in the new species. In both $L$. exilipes and $L$. atypicus, with equally long middle and inner terminal claws of leg 4 , the genital somite is produced posteriorly on both sides of the abdomen (Ho \& Lin 2004), a character absent in the new species; also, in both species the second maxillar segment has a pectiniform process which is absent in the new species. Moreover, both species have a bifurcate maxillular process, thus diverging from L. alvaroi sp. nov., which has a simple process (Fig. 1E). Another Pacific species with a general resemblance with L. alvaroi sp. nov. is L. mugiloidis Villalba \& Durán, 1985, both have similar body proportions, a reduced abdomen, identical armature of leg 1 and distal elements of leg 4 (with inner element only slightly longer than medial one). Differences include a posteriorly produced genital complex in L. mugiloidis, a bifid maxilla, a reduced first exopodal spine of leg 4 , and a sternal furca with clearly wider tines than in the new species (see Villalba \& Durán 1985).

There are two other species, both known also from the Eastern Tropical Pacific, that have the same general combination of characters including, most importantly, an unbranched maxillular process and a similar structure and armature of leg 4 , with the middle claw as long as the inner one. These are L. dissimulatus Wilson, 1905 and L. clarionensis Shiino, 1959. With respect to the former species, it differs from $L$. alvaroi sp. nov. in the following characters: the length/width ratio and shape of the genital complex is different in both species; in L. dissimulatus the genital complex is relatively larger than in L. alvaroi sp. nov. and only slightly longer than wide; the abdomen is clearly shorter than in the new species (see Shiino 1959, fig.15A). This species is easily distinguished by having a pair of posterior subtriangular processes in the postero-lateral margin of the genital complex, which are absent in the new species (see Wilson, 1905; Castro \& Baeza 1981; Fig. 1A). Also, in L. dissimulatus the middle seta of the fifth leg is clearly shorter than the other two (see Castro \& Baeza 1981, fig 6) $v s$. a middle seta equal to the outer one in the new species (Fig. 2G).

Lepeophtheirus clarionensis Shiino, 1959 from Isla Clarión, a Mexican Pacific oceanic island, is probably the most similar to L. alvaroi sp. nov. Like the new species, it has a short abdomen, an unbranched maxillular process and a leg 4 with two exopodal elements (inner and middle ones) of the same size (see Shiino 1959 , figs.14C, K). It differs from the new species in the proportions and shape of the genital complex; it is subrectangular vs. rounded in $L$. 
alvaroi sp. nov.; it is also clearly larger, about half as wide as the cephalothorax whereas this structure is about $1 / 3$ as wide. The cephalothorax has a different shape in both species; it is more robust and widest at its distal $1 / 3$ in the new species, whereas it is relatively uniformly wide in L. clarionensis (see Shiino 1959, fig. 14A). Legs 4 are longer in our specimens from Isla del Coco, they reach the distal margin of the caudal rami, whereas these are clearly shorter in L. clarionensis, barely reaching beyond half length of the genital complex (Shiino 1959, fig. 14A). The first segment of the maxilla is shorter than the second segment in L. clarionensis (Shiino 1959, fig.14D) whereas it is relatively longer in the new species. Also, the fifth leg is armed with a single seta (see Shiino 1959, fig.14M) vs. a set of three setae in L. alvaroi sp. nov. (Fig. 2G).

Overall, it is concluded that the new species has a unique combination of diagnostic characters that includes: rounded genital complex without posterior processes, a short, 1 -segmented abdomen less than half the length (about 25\%) of the genital complex, a simple, unbranched maxillular process, first segment of maxilla longer than second, the latter unarmed, leg 4 with a 3 -segmented exopod which is longer than the protopod, spine on first exopodal segment well developed, third segment of exopod with the middle terminal claw as long as the inner one, and a short, broad leg 5 armed with three setae.

\section{DISCUSSION}

The host of this species remains unknown, it was recorded in plankton samples; many caligids are found in the water column and this has been deemed as a possible, little known life mode of these parasites (Venmathi Maran $\&$ Ohtsuka 2008). Some species, such as Caligus undulatus Shen \& Li, 1959 have been recorded only from the plankton. This also may be the case for the specimens reported herein. Parasitological surveys of the local ichthyofauna of Isla del Coco should provide additional elements about this species. Members of Lepeophtheirus have been recorded in many different teleost families, and in the Eastern Pacific hosts include species belonging to Sciaenidae, Tetraodontidae, Balistidae, Labridae, and Serranidae (Shiino 1959, Causey 1960, Ho et al. 2001).

Most species of Caligus have been found to parasitize mainly warm water fishes distributed in low latitudes; contrastingly, members of Lepeophtheirus are found mostly on fish from cold water at higher latitudes. Hence, despite being the second most speciose group of the Caligidae, the diversity of this genus in tropical areas tends to be low, i.e., only three species have been recorded in waters of Taiwan vs. 34 of Caligus (Ho \& Lin 2004), and 4 vs. +25 of Caligus in Brazilian waters (Boxshall \& Montú 1997, Luque \& Tavares 2007). The same tendency is true in the Eastern Tropical Pacific; Shiino (1959) reported 8 species of Caligus and 3 of Lepeophtheirus and Causey (1960) 8 vs. 2 species, respectively. In Chilean waters, at lower and intermediate latitudes of the South Pacific, the number of species of these genera is almost equal (12 Caligus vs. 11 Lepeophtheirus) (Muñoz \& Olmos 2007).

\section{ACKNOWLEDGMENTS}

This work was possible with the kind support from colleagues and technicians collaborating in the field during the sampling period at Isla del Coco. We are particularly indebted to Jorge Picado and Jairo García for their help and advice during field work. We are especially grateful to Alvaro Morales-Ramírez, who kindly allowed us to examine these specimens. We also appreciate the support from the Vicerrectoría de Investigación of the University of Costa Rica through projects 808-3A-062 and 808-B0-060. Rosa Ma. Hernández Flores, El Colegio de la Frontera Sur (ECOSUR) provided the catalogue number of the Zooplankton collection at ECOSUR. We appreciate the useful comments from three anonymous reviewers. 


\section{RESUMEN}

Entre los varios grupos de copépodos que son parásitos de teleósteos, la familia sifonostomatoide Caligidae incluye los más dispersos y diversos. Con más de 108 especies nominales, el género de calígidos Lepeophtheirus von Nordmann es uno de los más diversos. No existen registros previos de este género en aguas de Costa Rica. Se describe una nueva especie de copépodo calígido del género Lepeophtheirus con base en especímenes femeninos recolectados a partir de muestras de plancton en aguas de Bahía Wafer, Isla del Coco, una isla oceánica del Pacífico Tropical Oriental. La nueva especie, L. alvaroi sp. nov., tiene algunas afinidades con congéneres que poseen un abdomen relativamente corto, un complejo genital más ancho que largo y un exópodo de la pata 4 con 3 segmentos. Esta especie difiere de la mayoría de estas especies por la presencia de un proceso maxilular no ramificado y por el tamaño relativo de las garras terminales de la pata 4, con dos elementos igualmente largos. Está más cercanamente relacionada con otras dos especies del Pacífico Oriental: $L$. dissimulatus Wilson, 1905 y L. clarionensis Shiino, 1959. Difiere de estas especies por las proporciones y forma del complejo genital, la forma de la furca esternal, la longitud relativa de los segmentos maxilares, la ausencia de un proceso pectiniforme en el segmento maxilar distal, la longitud de la pata 4 y la armadura de la pata 5 . La nueva especie representa el primer Lepeophtheirus descrito en aguas del Pacífico de Costa Rica. La baja diversidad del género en esta región tropical se explica por su tendencia a preferir hospederos de latitudes templadas. Hasta encontrar más evidencia, el hospedero de esta especie de Lepeophtheirus permanece desconocida.

Palabras clave: crustáceos parásitos, zooplancton, diversidad, copépodos, nueva especie, Isla del Coco, Costa Rica

\section{REFERENCES}

Boxshall, G.A. \& D.R. Bellwood. 1981. A redescription of Lepeophtheirus erecsoni Thomson, 1891 and some comparisons with L. scutiger Shiino, 1952 and a new species, L. sheni (Crustacea: Copepoda). J. Roy. Soc. N. Z. 11:75-85.

Boxshall, G.A. \& M.A. Montú. 1997. Copepods parasitic on Brazilian coastal fishes: a handbook. Nauplius 5: $1-225$.

Boxshall, G.A. \& S.H. Halsey. 2004. An Introduction to Copepod Diversity. The Ray Society, London, United Kingdom.

Castro, R. \& H. Baeza. 1981. Lepeophtheirus dissimulatus Wilson, 1905 and Lepeophtheirus zbigniewi new species (Copepoda: Caligidae) parasites of inshore fishes from the Pacific coast of Chile, South America. Bull. Mar. Sci. 3: 318-328.
Causey, D. 1960. Parasitic Copepoda from Mexican coastal fishes. Bull. Mar. Sci. 10: 323-337.

Cressey, R. \& H.B. Cressey. 1980. Parasitic copepods of mackerel- and tuna-like fishes (Scombridae) of the World. Smithson. Contr. Zool. 311:1 -186.

Dojiri, M. 1979. Two new species of Lepeophtheirus (Copepoda: Caligidae) parasitic on fishes from southern California waters. Parasitology 78: 251-262.

Graziano, L. 2001. Cruise Report S-177, Scientific Activities Undertaken Aboard SSV Robert C. Seamans, San Diego, California-Puntarenas, Costa Rica, October 10 2001-November 18, 2001. Sea Education Association, Woods Hole, Massachusetts. 45p.

Ho, J.-s., Gómez S., Fajer-Avila E. 2001: Lepeophtheirus simplex sp. n., a caligid copepod (Siphonostomatoida) parasitic on "botete" (bullseye puffer, Sphoeroides annulatus) in Sinaloa, Mexico. Folia Parasitol. 48: 240-248.

Ho, J.-S. \& C.-L. Lin. 2004. Sea Lice of Taiwan (Copepoda: Siphonostomatoida: Caligidae). The Sueichan Press, Keelung, Taiwan.

Jackson, D. \& D. Minchin. 1992. Aspects of the reproductive output of two caligid copepod species on cultivated salmon. Invertebr. Reprod. Dev. 22: 87-90.

Johnson, S. C., J. W. Treasurer, S. Bravo, K. Nagasawa \& Z. Kabata. 2004. A review of the impact of parasitic copepods on marine aquaculture. Zool. Stud. 43: 229-243.

Kabata, Z. 1979. Parasitic Copepoda of British Fishes. The Ray Society, British Museum, London, United Kingdom.

Luque, J.L. \& L.E.E. Tavares. 2007. Checklist of Copepoda associated with fishes from Brazil. Zootaxa 1579: $1-39$.

Morales-Ramírez, A. 2008. Caracterización cualitativa del zooplancton del Área de Conservación Marina Isla del Coco (ACMIC), Océano Pacífico de Costa Rica. Rev. Biol. Trop.56 (Supl. 2): 159-169.

Muñoz, G. \& V. Olmos. 2007. Revisión bibliográfica de especies ectoparásitas y hospedadoras de sistemas acuáticos de Chile. Rev. Biol. Mar. Oceanogr. 42: 89-148.

Shiino, S.M. 1959. Ostpazifische parasitierende Copepoden. Rep. Fac. Fish. Pref. Univ. Mie 3: 267-333.

Villalba, C. \& L. Durán. 1985. Lepeophtheirus mugiloidis sp. n. (Copepoda: Caligidae), parasito de Mugiloides chilensis (Molina, 1782) (Pisces: Mugiloididae), en Chile. Bol. Soc. Biol. Concepción 56: 59-66.

Venmathi Maran, B.A. \& S. Ohtsuka. 2008. Descriptions of caligiform copepods in plankton samples collected from East Asia: accidental occurrences or a new mode of life cycles? Plankton Benthos Res. 3: 202-215.

Wilson, C.B. 1905. North American parasitic copepods belonging to the family Caligidae. Part 1 . The Caliginae. Proc. U.S. Nat. Mus. 28: 479-672. 